\title{
Introduction (to CRESSE Special Issue of RIO)
}

\author{
Yannis Katsoulacos ${ }^{1} \cdot$ Bill Kovacic $^{1} \cdot$ Thomas Ross $^{1}$ \\ Published online: 18 June 2018 \\ (c) Springer Science+Business Media, LLC, part of Springer Nature 2018
}

\section{Introduction}

This Special Issue of the Review of Industrial Organization is devoted to an examination of competition policy and its enforcement, with a focus on the policy aspects that are of particular interest to younger jurisdictions in developing countries. Some of the articles are based on presentations that were made in sessions that were related to competition policy developments in developing countries at the 12th CRESSE Conference on Competition and Regulation that took place in July 2017. ${ }^{1}$ Additionally, some articles are based on presentations that were made during the special session on competition policy that was co-organized by CRESSE and the 2nd World Congress on Comparative Economics that took place in St. Petersburg in June 2017.

With the unprecedented global growth of competition policy enforcement in the last 15 years-with over 130 Competition Agencies operating at present worldwide - the issues that relate to the appropriate design of competition law, enforcement procedures, and institutional regimes have gained added significance. Much of this recent expansion has involved the introduction of new laws and agencies in developing countries within very different national contexts than those in the experienced developed world. As a result, it has become very important to take stock of how competition policy and law have been implemented in developing countries, recognizing the progress and gains that have been achieved as well as the challenges and persistent problems that remain.

\footnotetext{
${ }^{1}$ CRESSE is an informal network of academics and professionals with an interest in Competition Policy and Sectoral Regulation. It was initiated in 2005, and since then it has organized an annual Conference in Greece with the support of a Scientific Committee that is composed of Joe Harrington, Yannis Katsoulacos, Pierre Regibeau, Patrick Rey, Tom Ross, and David Ulph. Since its inception, CRESSE (www. cresse.info) has grown to become an important annual event worldwide in the competition and regulation conference calendar. The Advisory Board of CRESSE includes Frederic Jenny, Bill Kovacic, Aviv Nevo, and Howard Shelansky. In recent years CRESSE has also been responsible for the organization or coorganization of a number of Policy Review Workshops and Conferences in many developing countries, including Brazil, Chile, China, India, South Africa, Thailand, and Vietnam (for the APEC countries).
}

Yannis Katsoulacos

yanniskatsoulacos@gmail.com

1 Athens University of Economics and Business, Athens, Greece 
This Special Issue brings together well known academics and practicing economists and lawyers who provide a comprehensive coverage of experience with enforcement in a number of important developing countries in which competition law has developed over the last 10-15 years; specifically, Chile, China, India, Russia, Pakistan, Bangladesh, and South Africa.

There is an interesting and wide range of topics covered:

- The links to and developments of Competition Policy, widely defined to include all of the policies that aim to enhance competition in an economy, and Competition Law enforcement, narrowly defined as antitrust and merger policy, in China (by Yongzheng Liu and Guangliang Ye) and in India (by Aditya Bhattacharya, Geeta Gouri and Oindrila De);

- The optimal institutional structure of competition authorities, with empirical evidence from the case of Russia (by Svetlana Avdasheva, Svetlana Golovaneva and Yannis Katsoulacos) and institutional design in South Asia countries (by Udai Mehta and Parveer Singh Ghuman);

- Cartel prosecution in Chile (by Umut Aydin and Nicolas Figueroa) and South Africa (by Willem Boschoff and Rossouw van Jaarsveld);

- Reforming merger policy in developing countries (by Boris Begovic and Dusan Popovic); and

- Enforcement in the area of abuse of dominance in China (by Xiao Fu and Guofu Tan) and in India (by Payal Malik, Naha Singh, Ram Tamara and Nisha Kaur Uberoi).

We hope that this issue will advance discussions and stimulate more research on the effective design of competition policy law, policy, and institutions in developing countries.

The guest-editors would also like to thank the General Editor, Lawrence J. White, for his support for this special issue.

Yannis Katsoulacos, Bill Kovacic, and Thomas Ross

March 2018. 